\title{
Impact of FDI and Electricity on the Economic Growth of Pakistan: A Long Run Cointegration and Causality Analysis
}

\author{
Umer Qazi ${ }^{1}$, Aftab Alam², Shahab Ahmad ${ }^{2} \&$ Rani Ambreen ${ }^{2}$ \\ ${ }^{1}$ HELP University, Kuala Lumpur, Malaysia \\ ${ }^{2}$ ABASYN University, Peshawar, Pakistan \\ Correspondence: Aftab Alam, Department of Management Sciences, ABASYN University, Peshawar, Pakistan. Tel: \\ 92-91-258-2996.
}

Received: November 11, 2020

Accepted: December 23, 2020

Online Published: March 2, 2021

doi:10.5430/rwe.v12n2p273

URL: https://doi.org/10.5430/rwe.v12n2p273

\begin{abstract}
Since the 1980s, analysts have been debating the effect of foreign direct investment (FDI) and electricity consumption (EC) on the economic growth (GDP) of developing countries. The purpose of the study is to estimate the long-run relationship between FDI, electricity consumption and GDP of Pakistan for the period of 1971 to 2017, using ARDL bounds testing, FMOLS and Canonicals cointegration regression. For causality analysis, the study uses a VECM approach for short-run causality directions and MWALD/Toda Yamamoto approach for the long-run causality directions. The cointegration results of all the approaches state that there exists a positive and significant long-run relationship between the concerned variables. The impact of electricity consumption on economic growth is very strong as compared to FDI. Moreover, in the short-run, there is a unidirectional causality running from FDI to GDP and GDP to EC. In the long-run causality, the study finds unidirectional causality for FDI and bidirectional causality for EC with GDP.
\end{abstract}

Keywords: FDI, electricity consumption, GDP, cointegration, causality, Pakistan

Jel Classification: F21, F43, Q43

\section{Introduction}

\subsection{Foreign Direct Investment in Pakistan}

To keep up with its development needs like other developing countries rapid industrialization is very relevant in Pakistan. Nevertheless, the low level of gross savings, poor public spending and a weak innovation level in technology are an obstacle to the cycle of industrialization. Developing countries have used international aid and support to resolve this disparity in the past. However, with globalization, the majority of developing countries transformed from grants and assistance dependent economies to market economies and the stimulus of investment in developing and emerging economies is seen as reviving the economic growth. Different analysts, agencies and policymakers across the globe agree that foreign direct investment (FDI) promotes the economic growth and addresses the economic problems (Mencinger, 2003). Since capital investment and technological advances serve as instruments for growth in the economy, FDI is therefore required to foster growth level of host countries (Wang, 2009).

The OECD Report in 2002 states that FDI is viewed by countries with weak economic conditions as the only source of economic development. FDI stimulates the host country's investment, growth and strengthens human capital and local organizations. It is a vital means for the transition of technology to emerging economies (Makki \& Somwaru, 2004). It reflects their interest level in foreign direct investment, as some organizations incur expenses by using state funds to draw up inflows of FDI (Ford, Rork, \& Elmslie, 2008). There are different FDI special treatments, which may include immunity from import duty, tax vacation, land and direct subsidies (Hanson, 2001). During the fiscal year ended June 30th, 2019, Pakistan failed to win the trust of foreign investors in the domestic economy as FDI was halved to $\$ 1.73$ billion as in the previous fiscal year 2017-18, FDI stood at $\$ 3.47$ billion. Investor confidence may have been diluted given the uncertainty concerning the adjustment of rate (rupee-dollar), completion of the IMF program, the fragile position on economic levels, and Pakistan's lowering credit rates by Fitch in December 2018. In 
the financial year 2019, foreign investment in Pakistan did not improve, as FDI inflows stayed significantly below last year and equity investment in stocks displayed a growing outflow.

In the financial year 2019, an enormous 50\% fall in FDI happened after an inter-connector debt of more than a $\$ 0.5$ billion was repaid by one power industry in October 2018. Apart from that, the telecommunications companies were also paying back their debts to international parent companies. Comparing with the net flow of $\$ 372$ million in 2017-18, the oil and gas sector gained \$308.8 million in net FDI in the fiscal year 2019. The second-largest net FDI in 2019 was $\$ 286.5$ million compared with $\$ 400.3$ million in 2018 in the financial industry. The Biggest setback in 2019 was disinvestment in coal power companies with $\$ 453.2$ as compared to $\$ 769.8$ million investment of last year. China remained Pakistan's largest foreign investor, as it spent \$547 million at the end of the year on 30 June 2019. However, it was about a quarter of the $\$ 2$ billion in the last fiscal year invested by China. After China, the United Kingdom is the 2nd largest source of FDI in Pakistan with $\$ 185.2$ million in the year 2019. This FDI was about $\$ 305$ million in the last fiscal year of 2018 (SBP, 2019).

\subsection{Electricity in Pakistan}

According to Balcilar et al. (2010); Dlamini et al. (2015); Sekantsi and Okot (2016) and Tamba et al. (2017) the shortage of energy in most economies throughout the world has recently increased rapidly. The demand for electricity is increasing day by day as it plays a key role in both developed and emerging countries social and economic development. It is yet to be decided that economic growth precedes the energy or vice versa. This debate has led the researchers to develop vibrant links and causality of economic growth with different determinants like FDI, capital, labour, energy etc. According to OECD (2007), energy consumption in developing economies is rising rapidly, due to a sharp rise in population, industrialization and other economic activities. The current policy forecast for the International Energy Agency predicts that by the year 2035, the growth rate of energy will rise by $1.4 \%$ per year.

According to UNEP (2011), non-OECD countries like China and India are growing incredibly. The continuous growth of energy consumption at one end helps in economic development but on the other hand, it bears drastic consequences and challenges due to the volatile prices of fossil fuels and global warming issues, both of which negatively affects the humans and other living species. These all raise a worldwide issue about energy security, leading to the relevance of the transformation to alternative energy sources.

Several studies show causality analysis between energy and economic growth. Causality is an essential indicator of a correct strategy decision. Pakistan, a nation facing an immense shortfall in electrification and a poorly developed network for energy which has weakened its economic growth. According to the latest estimate by the CIA (2018), about 49.5 million people that accounts for $27 \%$ of the population in Pakistan has no access to electricity. Therefore according to Khan and Ahmad (2008); Shahbaz and Feridun (2012) to fulfil the demand of electricity the country depends upon a mechanism called the load shedding. The present generation power of electricity in Pakistan is 12,000 billion Megawatts per day, whereas the demand per day stands between 15,000 to 20,000 billion MW (CIA, 2018). As the demand for energy is rising at a sharp pace so, if the energy sector of Pakistan is not given appropriate consideration, then the situation will intimidate to become more relentless. At present, the demand for electricity is more than the supply. This gap is managed by load shedding for an average time of 10 and 18 hours in urban and rural areas of Pakistan respectively (Balcilar et al. 2019).

\section{Contribution of the Study}

- This particular study will contribute in establishing that in the current era of modern Information and communication technology (ICT), the energy, especially in the form of electricity, keeps great importance. Electricity is considered to be a vital input in the growth of an economy and this study will also try to prove a close relationship and interdependence of electricity and economic growth. Since the economy develops with more and more production process, and such process requires more electricity.

- This study also gives importance to the role of FDI in economic development. Beyond doubt, there are different ways in which the FDI contributes to the economy, but this study focuses on the FDI to be invested in a particular sector which is energy sector and energy sector can further assist in the economic growth.

- As Pakistan is a middle-lower income country, and currently has energy shortage problems, which reflects in a high rate of load-shedding and heavy circular debts. As a result, each sector (Manufacturing, Agriculture, Services) is affected badly and resulting in a negative per capita GDP or lower absolute GDP. The country needs sufficient electricity supply to run all the sectors smoothly for which the domestic investments are not adequate. This study will need the attention of policymakers to devise such strategies which can attract more foreign investments especially in 
the energy sector and related infrastructure. It will automatically raise the labour force and output and will further result in better GDP. For student researchers, the study might uncover further research by focusing on more reliable and cost-effective energy sources in Pakistan and their nexus with economic growth.

\section{Literature Review}

\subsection{FDI and Economic Growth}

The source of FDI was clarified by several hypotheses. According to Williamson (1985) and Dunning and Lundan (2008), international companies only conduct FDIs, if they fulfil conditions like possession benefits, location benefits and other globalization benefits. Possession benefits demand that a company must have certain advantages over other firms such as size, technological innovation, the promotional network, reach to the capital with low-interest rates etc. Location-based benefits mean that for a developed nation it is cheaper to produce goods and services in other less-developed nations and then further exporting from that foreign country. Such kind of advantages can be achieved by natural resources, cheap labour, easy trading agreements in a foreign country etc. In many countries, conceptual and empirical evidence has demonstrated that FDI is seen as an important pillar of economic expansion. FDI's position is obvious because it leads to economic growth by drivers such as the introduction of extra capital spending, export promotion, technical assistance, human resources development and employment etc. FDI also makes a positive difference to fiscal revenues and facilitates deep absorption into the international economy.

The effect of FDI and government policy on Taiwan's economy was studied by Bende-Nabende and Ferd (1998). They concluded that FDI is capable of boosting economic growth and reforms are capable of promoting growth, specifically in infrastructure investment and trade liberalization. Khawar (2005) analyzed the relationship between FDI and GDP in a panel of Latin America and African countries from the period of 1970 to 1992. She found a noteworthy and constructive impact of FDI over the GDP. A significant positive relationship between the FDI and GDP for the Sub Saharan African countries was found by Adams (2009). Agrawal and Khan (2011) studied the effects of FDI on the GDP of China and India from 1993 to 2003. They found both the variables have a long-run relationship, but in China, the impact of FDI is more significant than in India.

Bekhet and Othman (2011) estimated the association between FDI, energy and GDP for Malaysia for the period of 1971 to 2009. They found a long-run association between all the variables. Causality analysis showed long-run causality from energy to FDI and energy to GDP. Shaari et al. (2012) examined the effect of FDI on annual GDP in Malaysia for the period 1972-2010 and showed that economic growth in Malaysia is affected by increasing FDI. There also existed bidirectional causality between GDP and FDI. Tintin (2012) studied the impact of FDI in a sample of 125 countries comprising of developed, developing and underdeveloped countries from the period of 1980 to 2010. The results stated that overall the FDI was positively affecting the economy in most of the countries, but the impact in developing countries was more significant than developed and underdeveloped countries. Umoh et al. (2012) examined the relation of FDI and economic growth in Nigeria for the period of 1970 to 2008.

They found the variables positive and significant in the long-run relationship, moreover, the causality was found from FDI to economic growth. Umer and Alam (2013) conducted a study on the relationship between GDP, energy and FDI in Pakistan and India from 1975 to 2008. In both, the countries variables were cointegrating in the long-run. In India, there was found unidirectional causality from electricity to FDI, electricity to GDP, and bidirectional causality between FDI and GDP. In the case of Pakistan, there was unidirectional causality from FDI to electricity and GDP to electricity. Aga (2014), analyze the impact of FDI over GDP in Turkey for the period of 1980 to 2012. Results showed no significant relationship and causality.

The relation between FDI and economic growth for a panel of BRICS countries for 1989 to 2012 was studied by Agrawal (2015) and found a long-run significant association between the two. Tang et al. (2016) analyzed the relationship between energy, capital stock, FDI, and economic growth in Vietnam for the period of 1971 to 2011 . All the variables were found positively associated to economic growth. Long and My (2018) examined the causal link between the FDI, power consumption and economic growth in Vietnam during the period of 1990 to 2015. They found a significant relationship between all the variables. Moreover, causality analysis showed bidirectional causality between FDI and GNI and a unidirectional causality between power consumption and GNI. Ali and Shaheen (2019) studied the relationship between FDI and economic growth for Pakistan for the period of 1971 to 2018 . They found that in both long and short-run the FDI significantly affects the economic growth of the country.

\subsection{Electricity Consumption and Economic Growth}

The endogenous growth theory proposed by Arrow (1962), i.e. technology acts as a direct contributor to the growth of the economy. Here technology signifies the plant, machinery, or the overall process of production. In the absence 
of adequate power supply (electricity), these plant and machinery are ineffective. As the law of thermodynamics states that without converting the energy, the production process cannot be controlled. So overall energy or particularly a form of energy (electricity) is not the solitary elements of technology, but are the most significant aspects to make certain that technology becomes an essential element for economic growth and can be used efficiently. The transformation of raw energy to usable energy also exemplifies high technological achievement.

The pioneering research work in this regard was done by Kraft and Kraft (1978) in the United States from the period of 1947 to 1974 . The study found a unidirectional causality from economic growth to energy consumption. Many studies have investigated either the long-run relationships with causality or only causality analysis. This particular review is mainly focused on developing and single country analysis. Empirical evidence concerning the direction of causality and long-run, short-run relationship derived from many of the investigations in this regard are not on the same page. There are four types of causality directions. In case the causality is one way, or unidirectional from energy to economic growth, it is called the growth hypothesis and indicates the significance of energy. In the case of unidirectional causality from economic growth to energy shows a conservation hypothesis, which means that by adopting energy conservation policies the economy will not be affected in major. Causality in either the direction from energy to economic growth and vice versa stands for bidirectional causality or a feedback hypothesis. It shows the interdependence of both energy and growth. The absence of causality shows the neutrality hypothesis; in such a case any conservation policy regarding the energy will not affect the growth of the economy (Apergis \& Danuletiu, 2014).

The main reason for that might be due to the contributions that have focused on different regions, periods, and have used different proxy factors for economic growth, and energy in particular. Electricity has been the desired and influential form of energy in the evolving economic sectors of the industrial economy. It has been a key element in enhancing the quality of life and has cooperated in the evolution of knowhow and technology. It is therefore generally believed that this kind of energy is also vital for growth of economy. In this regard, Chandran et al. (2010); Tiwari (2011b); Yasmin et al. (2013) reported uni-directional causality from electricity consumption to economic growth (growth hypothesis) in Malaysia, India and Pakistan respectively. Similarly, Ameyaw et al. (2016), Balcilar et al. (2019), and Ghosh (2002) reported uni-directional causality from economic growth towards electricity i.e. conservation hypothesis in Ghana, Pakistan and India respectively.

On the contrary a bi-directional causality was reported i.e. economic growth causes electricity and vice versa, in Turkey, Portugal and Pakistan respectively (Aslan, 2014); (Shahbaz et al., 2011); and (Shahbaz \& Lean, 2012).

\section{Gaps in Literature Review}

- A country's economic growth might be steady but if the population growth increases too much as compared to the GDP, then per capita GDP will be negative. Such a case is not an issue for developed countries as they have a low controlled population and moderate pace of GDP is always higher than the population speed. But in the case of a country like Pakistan with a high rate of a population, the GDP per capita will be negative. Therefore in contrast to prior studies, this research has used the absolute value of GDP as well the absolute independent variables.

- Fully dynamic specification of an economic production function requires the inclusion of Capital and Labour in an equation. Most of the studies in the literature regarding Pakistan are lacking this, by using a bivariate or partial production function estimation which can result in omitted variable bias. Therefore this study uses a dynamic production function by including Labour and Capital in the estimation.

\section{Methodology Framework}

\subsection{Data}

In this study data from the period of 1971 to 2017 is used in the consideration of a dynamic relationship between the economic growth (GDP), capital (k), labor (L), foreign direct investment (FDI), and electricity consumption (EC). The data was selected from World Bank Development Indicators (WDI) (2018) (https://data.worldbank.org/indicator).

\subsection{Model Specification}

This study uses the multivariate regression model for Cobb Douglas production function (Cobb, 1928).

$$
Y=(L, K)
$$

The production function has been augmented by adding the variables of FDI and electricity consumption following (Long, Ngoc, \& My, 2018).

$$
Y=(\mathrm{L}, \mathrm{K}, \mathrm{FDI}, \mathrm{EC})
$$


Where,

$\mathrm{Y}=$ Economic growth (GDP) constant in local currency unit.

$\mathrm{L}=$ Labor force in absolute numbers.

$\mathrm{K}=$ Domestic gross fixed capital in local currency unit.

$\mathrm{FDI}=$ Foreign direct investment in local currency unit.

$\mathrm{EC}=$ Electricity consumption $\mathrm{kWh}$ per capita.

Data is transferred to log form for removing the skewness and achieving homoskedasticity as shown equation 3.

$$
\mathrm{LGDP}=\beta_{0}+\beta_{1} \mathrm{LL}+\beta_{2} \mathrm{LK}+\beta_{3} \mathrm{LFDI}+\beta_{4} \mathrm{LEC}+u t
$$

$\beta 0$ is the slope, ut is the error term and $\beta 1, \beta 2, \beta 3, \beta 4$ are the coefficient estimates of independent variables.

\subsection{Unit Root Testing}

Before going to proper cointegration, it very important to check the unit root or stationarity level of data. The property of stationarity affects the behavior of the whole time series data. In case of a data with unit root the persistence of shocks will be infinite and will result in spurious regression later on in spite of having a high $\mathrm{R}^{2}$ value, moreover the tration will not follow the $t$ distribution. Whereas if the data has no unit root then the shocks across the time will be minimized, moreover the there will be no variation in the mean, variance and autocorrelation across the time. The study will use Augmented Dickey-Fuller (ADF) unit root test (Dickey and Fuller 1979) to confirm that the degree of integration is not of order 2. The ADF model used in this study is given in equation 4, 5 and 6 respectively as:

$$
\begin{gathered}
\Delta Y_{t}=\beta Y_{t-1}+\sum_{i=1}^{k} a_{i} \Delta Y_{t-1}+\mu_{t} \text { (Without constant and trend) } \\
\Delta Y_{t}=\alpha_{0}+\beta Y_{t-1}+\sum_{i=1}^{k} a_{i} \Delta Y_{t-1}+\mu_{t} \text { (With constant and no trend) } \\
\Delta Y_{t}=\alpha_{0}+\beta Y_{t-1}+\gamma T+\sum_{i=1}^{k} a_{i} \Delta Y_{t-1}+\mu_{t} \text { (With constant and trend) }
\end{gathered}
$$

Where $\Delta Y_{t}=Y_{t}-Y_{t-1}$. This Yt represents one of the four variables of GDP, Labour, Capital, FDI and Electricity consumption, $\alpha_{0}$ is the constant, $\gamma \mathrm{T}$ is the deterministic trend, $\mathrm{t}$ is the time period and $\mu$ is the stochastic error term. Test of ADF is demonstrated in Table 1.

\subsection{Cointegration}

This study would explore the long-run relation between GDP, labor, capital, FDI and electricity consumption following the Autoregressive Distributed Lag (ARDL) bounds technique established by Pesaran and Pesaran (1997); Pesaran et al. (2000) and Pesaran et al. (2001). According to Pesaran and Pesaran (1997) this model can be utilized without analyzing the stationarity in data. As compared to the cointegration tests like, Engle and Granger (1987); Johansen and Juselius (1990) and Phillips and Hansen (1990), the ARDL is considered to be robust in outcomes for small data set (Haug, 2002). According to Laurenceson and Chai (2003) ARDL is very useful as in a general to specific approach, the unrestricted ECM of ARDL takes the satisfactory lags level to capture the data generating process. To take decision about the presence of cointegration between the variables in ARDL bounds test, F-stat value will be analyzed with lower and upper critical bounds.

In case the value of F-stat is more than the upper bound, cointegration exists, if lower than lower critical bound then no cointegration and in a case the value is between lower and upper bounds then the result will be inconclusive (Pesaran \& Pesaran, 1997); (Pesaran et al., 2001). To get an overview of short-run ECM under ARDL will be analyzed. It will also tell about the speed of adjustment through error correction term (ECT) or factor loading. Apart from cointegration some diagnostic tests like Heteroskedasticity, Serial Correlation, Histogram- Normality Test, functional form like Ramsey RESET and stability diagnostic tests like CUSUM and CUSUM of squares are performed. For the robustness of cointegration, the study will also use tests like Fully modified ordinary least squares (FMOL) and Canonical cointegration regression (CCR). Following are the ARDL models with dependent variable GDP and the incorporation of unrestricted lag of regressors.

Model 1:

$$
\begin{gathered}
\Delta L G D P= \\
\alpha_{1}+\sum_{i=1}^{n} \alpha_{i} \Delta L G D P_{t-i}+\sum_{a=0}^{n} \alpha_{a} \Delta L L_{t-a}+\sum_{b=0}^{n} \alpha_{b} \Delta L K_{t-b}+\sum_{c=0}^{n} \alpha_{c} \Delta L F D I_{t-c}+\sum_{d=0}^{n} \alpha_{d} \Delta L E C_{t-d}+ \\
\gamma_{1} L G D P_{t-1}+\gamma_{2} L L_{t-1}+\gamma_{3} L K_{t-1}+\gamma_{4} L F D I_{t-1}+\gamma_{5} L E C_{t-1}+\varepsilon_{1 t}
\end{gathered}
$$


Where $\Delta$ shows the first difference operator, $\alpha 1$ is unrestricted intercept, $\alpha_{n}, n=(i, a, b, c, d)$ are short term coefficients, $\gamma$ represents the long-run coefficients and $\varepsilon_{\mathrm{t}}$ represents a white noise error term. The estimate of short-run dynamic error correction term can be deducted from the equation no 8 as following.

$$
\begin{gathered}
\Delta L G D P= \\
\alpha_{1}+\sum_{i=1}^{n} \alpha_{i} \Delta L G D P_{t-i}+\sum_{a=0}^{n} \alpha_{a} \Delta L L_{t-a}+\sum_{b=0}^{n} \alpha_{b} \Delta L K_{t-b}+\sum_{c=0}^{n} \alpha_{c} \Delta L F D I_{t-c}+\sum_{d=0}^{n} \alpha_{d} \Delta L E C_{t-d}+ \\
\lambda E C T_{t-1}+u_{t}
\end{gathered}
$$

Where: $\mathrm{ECT}_{\mathrm{t}-1}$ is the error correction term and $\lambda$ represents the speed of adjustment.

As ARDL is the major long-run cointegration method in this study and the study is focused on the impact of Electricity and FDI on the GDP, therefore (Model-1) equation 7 and 8 will be processed only.

\subsection{Causality Test}

To examine the short and long-run causality, the study will use conventional granger causality under VECM and MWALD causality under augmented VAR model respectively. As compared to the short-run conventional granger causality the MWALD is a modified version and is also known as Toda Yamamoto approach developed by Toda and Yamamoto (1995). Wald test and long likely hood test under ECM acts very sensitively to specify the short-run dynamics, no matter how large the sample is (Zapata \& Rambaldi, 1997). For MWALD first of all the order of maximum integration is pre-specified i.e. $\left(d_{\max }\right)$ and the optimal lags order $(k)$ for the VAR. $\left(d_{\max }\right)=1$, is considered to be the best as compared to other lag orders as explained by (Dolado \& Lu tkepohl, 1996). Following are TY models, estimating the augmented $\operatorname{VAR}\left(k+d_{\max }\right)$ model of all the variables.

$$
\begin{aligned}
& \boldsymbol{L G D P}_{\boldsymbol{t}}=\alpha_{0}+\sum_{i=1}^{k} \beta_{1 i} L G D P_{t-i}+\sum_{j=k+1}^{d \max } \beta_{2 j} L G D P_{t-j}+\sum_{i=1}^{K} \beta_{3 i} L L_{t-i}+\sum_{j=k+1}^{d m a x} \beta_{4 j} L L_{t-j}+\sum_{i=1}^{k} \beta_{5 i} L K_{t-i}+ \\
& \sum_{j=k+1}^{d m a x} \beta_{6 j} L K_{t-j}+\sum_{i=1}^{k} \beta_{7 i} L F D I_{t-i}+\sum_{j=k+1}^{d m a x} \beta_{8 j} L F D I_{t-j}+\sum_{i=1}^{k} \beta_{9 i} L E C_{t-i}+\sum_{j=k+1}^{d m a x} \beta_{10 j} L E C_{t-j}+\varepsilon_{1 t} \\
& \boldsymbol{L L}_{\boldsymbol{t}}=\alpha_{0}+\sum_{i=1}^{k} \beta_{1 i} L L_{t-i}+\sum_{j=k+1}^{d \max } \beta_{2 j} L L_{t-j}+\sum_{i=1}^{K} \beta_{3 i} L G D P_{t-i}+\sum_{j=k+1}^{d \max } \beta_{4 j} L G D P_{t-j}+\sum_{i=1}^{k} \beta_{5 i} L K_{t-i}+ \\
& \sum_{j=k+1}^{d \max } \beta_{6 j} L K_{t-j}+\sum_{i=1}^{k} \beta_{7 i} L F D I_{t-i}+\sum_{j=k+1}^{d \max } \beta_{8 j} L F D I_{t-j}+\sum_{i=1}^{k} \beta_{9 i} L E C_{t-i}+\sum_{j=k+1}^{d \max } \beta_{10 j} L E C_{t-j}+\varepsilon_{1 t} \\
& \boldsymbol{L K}_{\boldsymbol{t}}=\alpha_{0}+\sum_{i=1}^{k} \beta_{1 i} L K_{t-i}+\sum_{j=k+1}^{d \max } \beta_{2 j} L K_{t-j}+\sum_{i=1}^{K} \beta_{3 i} L G D P_{t-i}+\sum_{j=k+1}^{d \max } \beta_{4 j} L G D P_{t-j}+\sum_{i=1}^{k} \beta_{5 i} L L_{t-i}+ \\
& \sum_{j=k+1}^{d m a x} \beta_{6 j} L L_{t-j}+\sum_{i=1}^{k} \beta_{7 i} L F D I_{t-i}+\sum_{j=k+1}^{d \max } \beta_{8 j} L F D I_{t-j}+\sum_{i=1}^{k} \beta_{9 i} L E C_{t-i}+\sum_{j=k+1}^{d m a x} \beta_{10 j} L E C_{t-j}+\varepsilon_{1 t} \\
& \operatorname{LFDI}_{\boldsymbol{t}}= \\
& \alpha_{0}+\sum_{i=1}^{k} \beta_{1 i} L F D I_{t-i}+\sum_{j=k+1}^{d \max } \beta_{2 j} L F D I_{t-j}+\sum_{i=1}^{K} \beta_{3 i} L G D P_{t-i}+\sum_{j=k+1}^{d \max } \beta_{4 j} L G D P_{t-j}+\sum_{i=1}^{k} \beta_{5 i} L L_{t-i}+ \\
& \sum_{j=k+1}^{d \max } \beta_{6 j} L L_{t-j}+\sum_{i=1}^{k} \beta_{7 i} L K_{t-i}+\sum_{j=k+1}^{d \max } \beta_{8 j} L K_{t-j}+\sum_{i=1}^{k} \beta_{9 i} L E C_{t-i}+\sum_{j=k+1}^{d \max } \beta_{10 j} L E C_{t-j}+\varepsilon_{1 t} \\
& \boldsymbol{L E C}_{\boldsymbol{t}}=\alpha_{0}+\sum_{i=1}^{k} \beta_{1 i} L E C_{t-i}+\sum_{j=k+1}^{d \max } \beta_{2 j} L E C_{t-j}+\sum_{i=1}^{K} \beta_{3 i} L G D P_{t-i}+\sum_{j=k+1}^{d \max } \beta_{4 j} L G D P_{t-j}+\sum_{i=1}^{k} \beta_{5 i} L L_{t-i}+ \\
& \sum_{j=k+1}^{d \max } \beta_{6 j} L L_{t-j}+\sum_{i=1}^{k} \beta_{7 i} L K_{t-i}+\sum_{j=k+1}^{d \max } \beta_{8 j} L K_{t-j}+\varepsilon_{1 t}
\end{aligned}
$$

\section{Results and Discussion}

It is important to know the exact integration order of all the variables in order to verify that no variable is stationary at $I(2)$. In a case the variables are integrated at $I(2)$, the calculation of $\mathrm{F}$ stat for the cointegration will be irrational (Ouattara, 2004). Table 1 shows the summary of unit root test. According to ADF test GDP, Labor, and Electricity consumption are non stationary at levels but becomes stationary in first difference at 5\% sig level. The variable of Capital is stationary in levels at $10 \%$ sig level with constant, while in case of (constant \& trend) and (no constant \& trend), Capital is non stationary. After differencing the Capital becomes stationary in all modes respectively. The variable of FDI is stationary at level in case of (constant) and (constant \& trend) and non stationary in case of (no constant \& trend). After first differencing FDI becomes stationary in all modes at $1 \%$ sig level. Overall there is a mix unit root test results with GDP, LL, LK and LEC as I(1) and LFDI as I(0).

Table 1. Augmented dickey-fuller test

Null Hypothesis: the variable has a unit root
\begin{tabular}{lllllll}
\hline \multicolumn{1}{c}{ At Level } \\
\hline & LGDP & LL & LK & LFDI & LEC \\
\hline With Constant & t-Statistic & -2.1495 & 0.1221 & -2.8720 & -2.6831 & -1.5894 \\
\hline
\end{tabular}




\begin{tabular}{|c|c|c|c|c|c|c|}
\hline & Prob. & 0.2271 & 0.9641 & 0.0581 & 0.0306 & 0.4798 \\
\hline & & No & No & $*$ & $* *$ & No \\
\hline \multirow[t]{3}{*}{ With Constant \& Trend } & t-Statistic & -1.5274 & -2.5443 & -2.3119 & -3.2143 & -0.9814 \\
\hline & Prob. & 0.8051 & 0.3066 & 0.4192 & 0.0039 & 0.9367 \\
\hline & & No & No & No & $* * *$ & No \\
\hline \multirow[t]{5}{*}{ Without Constant \& Trend } & t-Statistic & 4.6211 & 6.9772 & 2.9134 & 1.2263 & 4.2287 \\
\hline & Prob. & 1.0000 & 1.0000 & 0.9988 & 0.9416 & 1.0000 \\
\hline & & No & No & No & No & No \\
\hline & At First D & erence & & & & \\
\hline & & $\mathrm{d}($ LGDP) & $d(L L)$ & $\mathrm{d}(\mathrm{LK})$ & $\mathrm{d}(\mathrm{LFDI})$ & $\mathrm{d}(\mathrm{LEC})$ \\
\hline \multirow[t]{3}{*}{ With Constant } & t-Statistic & -5.0775 & -7.0527 & -5.1769 & -3.9569 & -5.7863 \\
\hline & Prob. & 0.0001 & 0.0000 & 0.0001 & 0.0039 & 0.0000 \\
\hline & & $* * *$ & $* * *$ & $* * *$ & $* * *$ & $* * *$ \\
\hline \multirow[t]{3}{*}{ With Constant \& Trend } & t-Statistic & -5.5841 & -6.9788 & -3.9111 & -4.6101 & -6.0212 \\
\hline & Prob. & 0.0002 & 0.0000 & 0.0212 & 0.0034 & 0.0000 \\
\hline & & $* * *$ & $* * *$ & $* *$ & $* * *$ & $* * *$ \\
\hline \multirow[t]{3}{*}{ Without Constant \& Trend } & t-Statistic & -0.4751 & -0.3395 & -3.9392 & -3.8425 & -2.7615 \\
\hline & Prob. & 0.5034 & 0.5558 & 0.0002 & 0.0003 & 0.0068 \\
\hline & & No & No & $* * *$ & $* * *$ & $* * *$ \\
\hline
\end{tabular}

a: (*)Significant at the 10\%; (**)Significant at the 5\%; (***) Significant at the $1 \%$ and (no) Not Significant

b: Lag Length based on SIC

c: Probability based on MacKinnon (1996) one-sided p-values.

After finding the integration level the study needs to check the appropriate lag length before the ARDL approach of cointegration. According to Bahmani-Oskooee and Brooks (1999); and Bahmani-Oskooee and Harvey (2006) the Fstat for ARDL is very sensitive to the criteria of lag length. Table 2 shows the most favorable lag length criteria, i.e. 6 years according to AIC and HQ.

Table 2. VAR lag order selection criteria

\begin{tabular}{lllllll}
\hline Lag & LogL & LR & FPE & AIC & SC & HQ \\
\hline 0 & 145.0070 & NA & $7.44 \mathrm{e}-10$ & -6.829611 & -6.620639 & -6.753515 \\
\hline 1 & 373.8471 & 390.7025 & $3.61 \mathrm{e}-14$ & -16.77303 & $\mathbf{- 1 5 . 5 1 9 2 0 *}$ & -16.31645 \\
\hline 2 & 400.5270 & 39.04383 & $3.52 \mathrm{e}-14$ & -16.85498 & -14.55628 & -16.01792 \\
\hline 3 & 426.4182 & 31.57459 & $3.92 \mathrm{e}-14$ & -16.89845 & -13.55489 & -15.68091 \\
\hline 4 & 468.3670 & $\mathbf{4 0 . 9 2 5 6 8 *}$ & $2.36 \mathrm{e}-14$ & -17.72522 & -13.33680 & -16.12720 \\
\hline 5 & 494.9384 & 19.44243 & $4.00 \mathrm{e}-14$ & -17.80187 & -12.36859 & -15.82337 \\
\hline
\end{tabular}

* indicates lag order selected by the criterion 
The results reported in Table 3 indicates that our computed F-statistics at 10 percent, 5 percent and 1 percent respectively are greater than the upper limits generated by Pesaran et al (2001). This study found four cointegrating vectors once the variables like GDP, Labor, Capital, FDI and Electricity consumption are considered as dependent variables. In case of Labor as the dependent variable the F stat value is lower than the upper bound of all the three limits, so no long-run cointegration has been found. As the subject matter of this study is impact of different factors on GDP, so the study will proceed with model 1 i.e. GDP as dependent variable.

Table 3. ARDL Bounds Test

\begin{tabular}{|c|c|c|c|c|c|}
\hline Models & Opt. Lag Length & F-Stat & R-Square & Adj.R-Square & D.W Value \\
\hline $\mathbf{F}_{\text {GDP }}($ LGDP/ LL LK LFDI LEC $)$ & $(1,4,3,4,0)$ & $16.76^{* * *}$ & 0.736 & 0.6423 & 1.96 \\
\hline $\mathbf{F}_{\mathbf{L}}(\mathrm{LL} /$ LGDP LK LFDI LEC) & $(1,2,6,0,3)$ & $2.483^{\text {No }}$ & 0.689 & 0.571 & 2.35 \\
\hline $\mathbf{F}_{\mathbf{K}}(\mathrm{LK} / \mathrm{LGDP}$ LL LFDI LEC $)$ & $(1,5,5,4,2)$ & $4.625^{* *}$ & 0.846 & 0.748 & 2.22 \\
\hline $\mathbf{F}_{\text {FDI }}($ LFDI/ LGDP LL LK LEC) & $(1,6,3,6,3)$ & $7.137 * * *$ & 0.842 & 0.714 & 1.8 \\
\hline $\mathbf{F}_{\mathbf{E C}}($ LEC/ LGDP LL LK LFDI $)$ & $(1,4,6,1,0)$ & $3.83^{*}$ & 0.508 & 0.313 & 2.11 \\
\hline Critical bounds & Lower Bounds & $\begin{array}{l}\text { Upper } \\
\text { Bounds }\end{array}$ & & & \\
\hline $10 \%$ & 2.402 & 3.345 & & & \\
\hline $5 \%$ & 2.85 & 3.905 & & & \\
\hline $1 \%$ & 3.892 & 5.173 & & & \\
\hline
\end{tabular}

(*)Significant at the 10\%; (**) Significant at the 5\%; (***) Significant at the 1\% and (no) Not Significant

ARDL long-run and short-run cointegration is shown in Table 4. It shows that all the variables have a positive and significant relationship. $1 \%$ rise in the independent variables of LL, LK, LFDI and LEC will raise the LGDP by $0.90 \%$, $0.55 \%, 0.03 \%$ and $0.49 \%$ respectively. More over the ECM value is negative and significant and shows that the system adjusts its previous years disequilibrium with a speed of $47 \%$ in the current year.

Estimation Equation:

$\mathrm{LGDP}=\mathrm{C}(1) * \mathrm{LGDP}(-1)+\mathrm{C}(2) * \mathrm{LL}+\mathrm{C}(3) * \mathrm{LL}(-1)+\mathrm{C}(4) * \mathrm{LL}(-2)+\mathrm{C}(5) * \mathrm{LL}(-3)+\mathrm{C}(6) * \mathrm{LL}(-4)+\mathrm{C}(7) * \mathrm{LK}+$ $\mathrm{C}(8) * \mathrm{LK}(-1)+\mathrm{C}(9) * \mathrm{LK}(-2)+\mathrm{C}(10) * \mathrm{LK}(-3)+\mathrm{C}(11) * \mathrm{LFDI}+\mathrm{C}(12) * \mathrm{LFDI}(-1)+\mathrm{C}(13) * \mathrm{LFDI}(-2)+\mathrm{C}(14) * \mathrm{LFDI}(-3)$ $+\mathrm{C}(15) * \mathrm{LFDI}(-4)+\mathrm{C}(16) * \mathrm{LEC}+\mathrm{C}(17)$.

Error Correction Term $($ ECT $)=$ LGDP- $(0.901 *$ LL+0.555*LK+0.034*LFDI+0.491*LEC-5.499

Table 4. ARDL Long and short-run estimates

\begin{tabular}{|c|c|c|c|c|}
\hline \multicolumn{5}{|c|}{ Dependent variable: LGDP } \\
\hline \multicolumn{5}{|c|}{ Long-run estimates } \\
\hline Variables & Coefficient & Std.Error & t-stat & $\mathrm{p}$-value \\
\hline $\mathrm{LL}$ & 0.901 & 0.031 & 28.983 & 0.0000 \\
\hline$\overline{\mathrm{LK}}$ & 0.555 & 0.048 & 11.521 & 0.0000 \\
\hline$\overline{\text { LFDI }}$ & 0.034 & 0.013 & 2.545 & 0.0172 \\
\hline$\overline{\mathrm{LEC}}$ & 0.491 & 0.185 & 2.648 & 0.0136 \\
\hline$\overline{\mathrm{C}}$ & -5.499 & 0.375 & 14.633 & 0.0000 \\
\hline \multicolumn{5}{|c|}{ Short-run estimates } \\
\hline $\mathrm{D}(\mathrm{LL})$ & 0.016 & 0.061 & 0.270 & 0.788 \\
\hline$\overline{\mathrm{D}(\mathrm{LL}(-1))}$ & -0.389 & 0.080 & -4.823 & 0.0001 \\
\hline
\end{tabular}




\begin{tabular}{lcccl}
\hline $\mathrm{D}(\mathrm{LL}(-2))$ & -0.300 & 0.075 & -3.970 & 0.0005 \\
\hline $\mathrm{D}(\mathrm{LL}(-3))$ & -0.223 & 0.080 & -2.761 & 0.0104 \\
\hline $\mathrm{D}(\mathrm{LK})$ & 0.163 & 0.034 & 4.686 & 0.0001 \\
\hline $\mathrm{D}(\mathrm{LK}(-1))$ & -0.111 & 0.040 & -2.772 & 0.0101 \\
\hline $\mathrm{D}(\mathrm{LK}(-2))$ & -0.146 & 0.038 & -3.833 & 0.0007 \\
\hline $\mathrm{D}(\mathrm{LFDI})$ & -0.000 & 0.004 & -0.115 & 0.9087 \\
\hline $\mathrm{D}(\mathrm{LFDI}(-1))$ & 0.015 & 0.004 & 3.689 & 0.0010 \\
\hline $\mathrm{D}(\mathrm{LFDI}(-2))$ & 0.005 & 0.004 & 1.390 & 0.1762 \\
\hline $\mathrm{D}($ LFDI $(-3))$ & 0.009 & 0.003 & 3.156 & 0.0040 \\
\hline CointEq(-1) & $\mathbf{- 0 . 4 6 7}$ & $\mathbf{0 . 0 4 2 7}$ & $\mathbf{- 1 0 . 9 5 2}$ & $\mathbf{0 . 0 0 0 0}$ \\
\hline
\end{tabular}

Table 5 shows some diagnostic tests. In Heteroskedasticity test, p-value of F-stat and observed $\mathrm{R}^{2}$ is $99.6 \%$ and $99 \%$ respectively that are greater than $5 \%$ so it means that the model is not Hetroskedastic. In serial correlation test, the p-value of $\mathrm{F}$ stat and observed $\mathrm{R}^{2}$ is $45 \%$ and $25 \%$ that are greater than $5 \%$, so there is no serial correlation. In histogram normality test the p-value Jarque-Berra test is $98 \%$ that is greater than $5 \%$, so the residuals are normally distributed. Stability of the model is checked through Ramsay test in which the p-values of $\mathrm{t}$ and $\mathrm{F}$ statistics are $25 \%$ each also greater than 5\% significance level, so there is no signs of non linearity in the model specification. CUSUM of Squares test is also used to know about small shifts in the process means. As in Figure 1, the plots are within the critical bounds of $5 \%$ level of significance, hence proved that error correction model is structurally stable.

Table 5. Residual and stability diagnostics

\begin{tabular}{|c|c|c|c|}
\hline \multicolumn{4}{|c|}{ Heteroskedasticity Test: Breusch-Pagan-Godfrey } \\
\hline F-statistics & 0.255 & Prob. F(16,26) & 0.996 \\
\hline Obs*R-squared & 5.846 & Prob. Chi-Square(16) & 0.989 \\
\hline \multicolumn{4}{|c|}{ Breusch-Godfrey Serial Correlation LM Test } \\
\hline F-statistics & 0.822 & Prob. $F(2,24)$ & 0.451 \\
\hline Obs*R-squared & 2.757 & Prob. Chi-Square(2) & 0.251 \\
\hline \multicolumn{4}{|c|}{ Histogram-Normality: Jarque-Bera Statistic } \\
\hline Jarque-Bera & 0.041 & P-value & 0.979 \\
\hline \multicolumn{4}{|c|}{ Ramsay RESET Test } \\
\hline & Value & Df & Prob. \\
\hline t-statistics & 0.050 & 25 & 0.247 \\
\hline F-statistics & 0.002 & $(1,25)$ & 0.247 \\
\hline
\end{tabular}

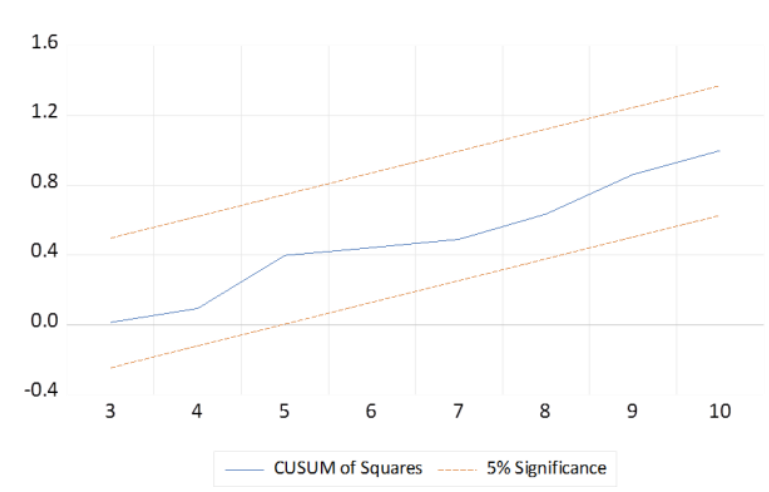

Figure 1. Plot of cumulative sum of squares 
For the robustness of the long-run cointegration between the concerned variables the study also utilizes the FMOLS and Canonical tests as shown in Table 6. As per their results all the variables are positive and significant. The ECM values are negative and significant validating the long-run association. Apart from that the no Heteroskedasticity and no serial correlation has been confirmed. The residuals are normally distributed as evident from the Jarque-Bera p-values of 0.95 and 0.73 respectively. Model specification through Ramsay RESET test in both the case is also normal.

Table 6. FMOLS and CCR estimates, dependent variable: LGDP

\begin{tabular}{lll}
\hline Variables & FMOLS & Canonical (CCR) \\
\hline LL & $1 * * *$ & $1 * * *$ \\
& $(0.039)$ & $(0.039)$ \\
\hline LK & {$[25.760]$} & {$[25.630]$} \\
\hline & $0.178^{* * *}$ & $0.123^{* *}$ \\
& $(0.054)$ & $(0.058)$ \\
LFDI & {$[3.282]$} & {$[2.115]$} \\
\hline LEC & $0.095^{* * *}$ & $0.098^{* * *}$ \\
& $(0.010)$ & $(0.010)$ \\
\hline C & {$[9.158]$} & {$[9.107]$} \\
\hline ECM & $0.292^{*}$ & $0.354^{* *}$ \\
& $(0.153)$ & $(0.161)$ \\
\hline R and Adj. R ${ }^{2}$ & {$[1.898]$} & {$[2.196]$} \\
\hline Heteroskedasticity Test & -0.504 & 0.419 \\
\hline Serial Correlation & $(0.512)$ & $(0.497)$ \\
\hline Histogram-Normality & {$[-0.985]$} & {$[0.842]$} \\
\hline Ramsay RESET & $-0.0765^{* *}$ & $-0.0693 * * *$ \\
\hline
\end{tabular}

The asterisks $* * *, * *$ and $*$ denotes significance level at 1,5 and 10 per cent.

Standard errors are reported in ( ), whereas t-stats in [ ] brackets.

Table 7. Short-run Granger Causality under VECM

\begin{tabular}{|c|c|c|c|c|c|c|}
\hline $\begin{array}{l}\text { Dep. } \\
\text { Variable }\end{array}$ & $\mathrm{D}(\mathrm{LGDP})$ & $\mathrm{D}(\mathrm{LL})$ & $\mathrm{D}(\mathrm{LK})$ & $\mathrm{D}(\mathrm{LFDI})$ & $\mathrm{D}(\mathrm{LEC})$ & Causality Direction \\
\hline D(LGDP) & - & -0.156 & -0.003 & $0.011 * *$ & 0.137 & $\mathrm{D}(\mathrm{LFDI}) \rightarrow \mathrm{D}($ LGDP $)$ \\
\hline$D(\mathbf{L L})$ & -0.199 & - & -0.006 & -0.006 & 0.191 & No Causality \\
\hline D(LK) & 0.888 & -0.106 & - & $0.023 * * *$ & 0.088 & $\mathrm{D}(\mathrm{LFDI}) \rightarrow \mathrm{D}(\mathrm{LK})$ \\
\hline D(LFDI) & 4.408 & $-6.613 * *$ & -0.192 & - & 3.316 & $\mathrm{D}(\mathrm{LL}) \rightarrow \mathrm{D}(\mathrm{LFDI})$ \\
\hline D(LEC) & $0.358 * * *$ & -0.071 & 0.029 & -0.001 & - & $\mathrm{D}($ LGDP $) \rightarrow \mathrm{D}($ LEC $)$ \\
\hline
\end{tabular}

The asterisks *, $* *$ and $* * *$ denotes significance level P-values at 1,5 and 10 per cent. 
Table 7 shows the short-run conventional Granger causality test via VECM approach, which states that in short-run $\mathrm{D}(\mathrm{LFDI})$ granger cause the $\mathrm{D}(\mathrm{LGDP})$ and $\mathrm{D}(\mathrm{LK})$, i.e. $\mathrm{D}(\mathrm{LFDI}) \rightarrow \mathrm{D}(\mathrm{LGDP})$ and $\mathrm{D}(\mathrm{LFDI}) \rightarrow \mathrm{D}(\mathrm{LK})$ showing a unidirectional causality. Next, D(LL) granger causes the LFDI having a unidirectional causality i.e. $\mathrm{D}(\mathrm{LL}) \rightarrow \mathrm{D}($ LFDI). Similarly $\mathrm{D}($ LGDP) causes the $\mathrm{D}($ LEC) i.e. $\mathrm{D}($ LGDP $) \rightarrow \mathrm{D}($ LEC) having a unidirectional causality.

Table 8 shows the long-run causality under Toda Yamamoto approach. The results state that a unidirectional causality is present from LL $\rightarrow$ LGDP, LFDI $\rightarrow$ LGDP, LFDI $\rightarrow$ LK, and LL $\rightarrow$ LEC. On the other hand bidirectional causality is present from $\mathrm{LK} \rightleftarrows \mathrm{LGDP}, \mathrm{LFDI} \rightleftarrows \mathrm{LEC}$, and LEC $\rightleftarrows \mathrm{LGDP}$.

Table 8. Long-run Granger Causality (MWALD) / (Toda Yamamoto Approach)

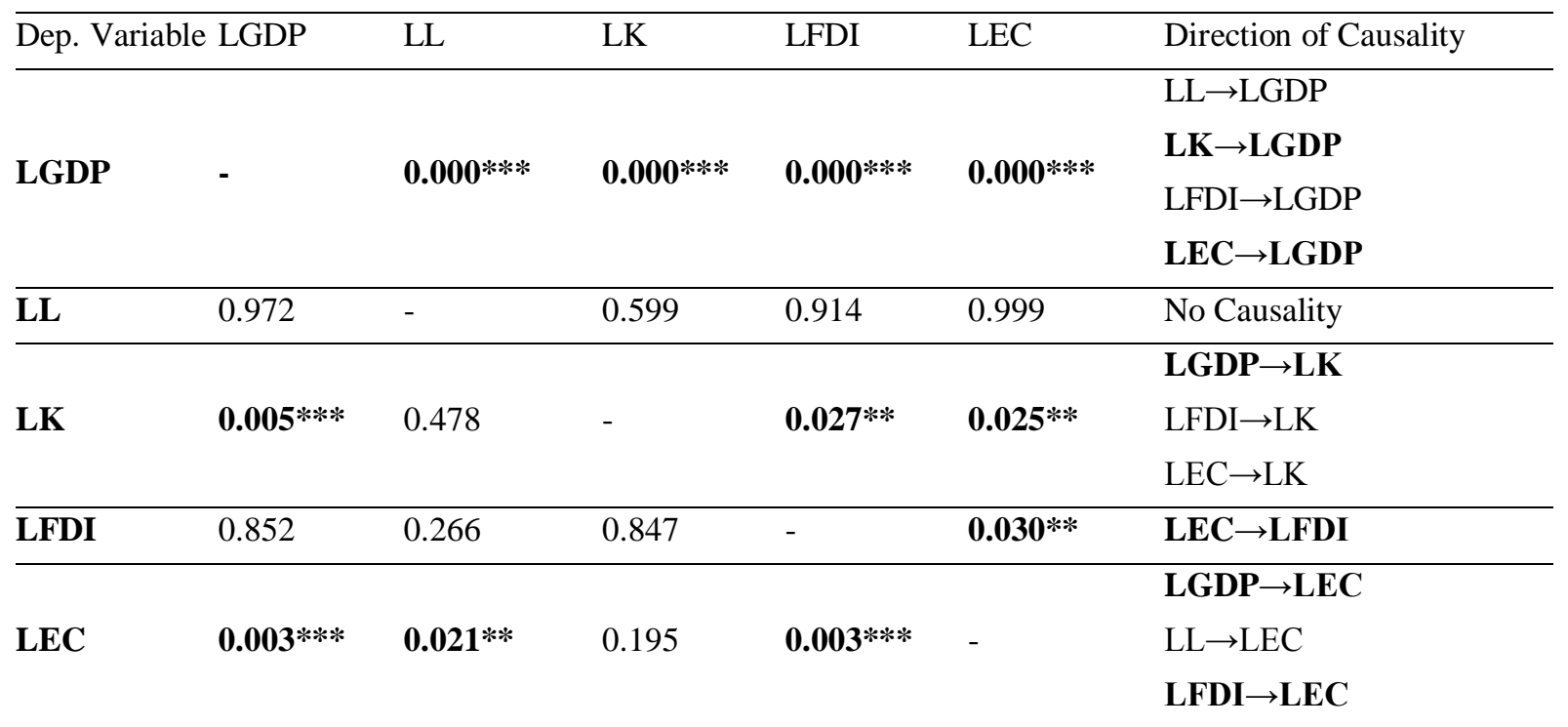

Endogenous Lags 6

Exogenous Lags $6+1=7$

\section{Further Discussion}

In the cointegration estimates from ARDL, FMOLS and CCR, it is evident that beta coefficients of EC variable are $0.49,0.29$ and 0.35 respectively, whereas the coefficients for FDI are $0.03,0.09$ and 0.09 respectively. This clearly shows that increased investments in the energy sector will benefit the economic growth of Pakistan more than increased investment in FDI. Therefore such policies which are going to attract more FDI and appraise the projects related to FDI needs to prefer such projects, which are capable to consume less electricity, use efficient technology and are pollution free. As in short-run causality D(LFDI) granger cause the D(LGDP) showing a unidirectional causality and $\mathrm{D}$ (LGDP) causes the $\mathrm{D}(\mathrm{LEC})$ having a unidirectional conservation causality. These results provide support to the findings of Acheampong (2018) for a panel of 116 countries, Cowan et al. (2014) for South Africa under BRICS nations, Kim (2019) for a panel of 57 countries, Kivyiro and Arminen (2014) for Sub Saharan African countries, Lee (2012); Park et al. (2019) for South Korea, Lee (2009) for Malaysia, Linh and Lin (2015) for a panel of Asian countries, Jamil and Ahmad (2010); Shahbaz and Faridun (2012) for Pakistan. The short-run results contradict the results by Aqeel and Butt (2001), Attari et al. (2011); Shahbaz and Leen (2012); Yasmin et al. (2013); Siddiqui and Siddiqui (2019), for Pakistan.

In the long-run there is a unidirectional causality between FDI and GDP, whereas there is a bidirectional Long-run causality between LEC and GDP. Toda Yamamoto causality provides support to the findings of Lean and Smyth (2010) and Tang (2008) for Malaysia, Shahbaz and Leen (2012) for Pakistan. This study contradicts the results in long-run causality by Balcilar et al. (2019), Jamil and Ahmad (2010); Shahbaz and Faridun (2012); Siddiqui and Siddiqui (2019) for Pakistan. The contradicting results in short-run and long-run causality analysis might be due to the omission of certain variables which are necessary for a dynamic growth model e.g. Capital and Labor. 
In the short and long-run causality the FDI is causing the GDP, which is a good sign of developing economy attracting more and more FDI. This is for sure that different factors like provision of business services, better infrastructure, sharing the market information and peace and security situation attract more foreign investments. On the other hand Electricity consumption has a bidirectional relation with GDP, which calls for more investment in the energy sector to generate more electricity to fulfil the consumption requirement of electricity, ultimately contributing in GDP growth.

\section{Conclusion}

This paper empirically examines the relationship between the foreign direct investment (FDI), electricity consumption (EC) and economic growth (GDP) in Pakistan over the time period of 1971 to 2017. For the purpose of long-run cointegration between the variables ARDL Bounds testing approach is utilized. ARDL confirmed that there is positive and significant long-run relationship between all the variables. Diagnostic tests also confirmed that, there is no Heteroskedasticity and serial correlation. Residual are normally distributed and specification test of RAMSAY is also perfect. CUSUM of Squares tests showed that parameters are stable. For the robustness of ARDL cointegration results, two more tests of cointegration were performed, that are FMOLS and Canonical cointegration regression (CCR). Both these tests confirmed the presence of positive and significant long-run relationship between the concerned variables.

To know about the causality short-run causality was analyzed via VECM approach. This showed that there is a unidirectional causality from FDI to GDP and GDP to EC. In the short-run the developing economy of Pakistan is attracting the FDI. Similarly when GDP is improved it affects the electricity consumption in the country. For the long-run causal effects TY approach was utilized. The analysis showed a unidirectional causality from FDI to GDP, bidirectional causality between FDI and EC, and EC and GDP.

\section{Policy Implications}

Policy makers should focus on such measures which can boost the foreign investment in the production and services sector of Pakistan. In the recent past the energy crises and security situation of the country has forced the FDI to go for the services sector of Pakistan instead of manufacturing sector, as the services sector is considered safer. In case to develop a sound domestic investment environment there is a need of careful and balanced allocation of foreign investment in the most productive sectors i.e. manufacturing and energy sectors. Bidirectional or feedback relationship between FDI and EC confirms that foreign investment is now focusing in the energy sector of Pakistan, and once the energy infrastructure is well developed it will be pretty feasible to attract more FDI as well flourish the domestic investment in terms of manufacturing. Moreover the GDP and EC have also feedback causality. As Pakistan is an emerging lower-middle income country, therefore with respect to the estimation results the policy makers should adopt two fold primary approaches, i.e. one by increasing the investment in research and development in green technology and other is to invest more in the energy infrastructure.

Unfortunately the economic growth cannot be attained in the presence of sever electricity shortages, therefore in such a case rather adopting the energy conservation policy, Country should focus on generating and supplying more electricity to curb the shortages by not only building more power plants but also saving the excessive use of domestic household electricity and reducing the technical and non technical line losses. Moreover the country is gifted in abundance with the natural resources like Sun light, water, Wind and Bio-fuel. By using these environmental friendly sources of energy, country can flourish in renewable energy market. These renewables energy sources will cut a large portion of cost incurred by imported energy sources in the form of fossil fuels like Oil, Gas and Coal.

\section{Limitations and Future Work}

The research is limited to a single region, i.e. Pakistan, and from the other hand, survey results are accessible at an annual level only and cover a very short period of time. Temporal aggregation into annual data may weaken the causal relations among the variables. Therefore the results found cannot be generalized or extended to other countries, depending on both kinds of limitations. The relationship between energy and GDP could be important in the future, using quarterly data. In fact, the panel analysis should provide an interesting comparison, enriching findings and more general assumptions with respect to different countries. This is study has also a limitation of not using structural break test.

In future the estimation model can be further expanded, and requires other factors, such as Domestic investments, Disaggregate electricity sources (oil, gas, nuclear, hydel, coal, solar, biogas, tidal and wind etc), Infrastructure development, Price of fuels and $\mathrm{CO} 2$ emissions with properly taking care of structural breaks in the data. This will specifically broaden the scope of such research studies with consistent outcomes by rather using only traditional energy sources in growth models. 


\section{References}

Acheampong, A. O. (2018). Economic growth, CO2 emissions and energy consumption: what causes what and where?. Energy Economics, 74, 677-692. https://doi.org/10.1016/j.eneco.2018.07.022

Adams, S. (2009). Can foreign direct investment (FDI) help to promote growth in Africa?. African Journal of Business Management, 3(5), 178-183. https://doi.org/10.5897/AJBM09.001

Aga, A. A. K. (2014). The impact of foreign direct investment on economic growth: A case study of Turkey 1980-2012. International Journal of Economics and Finance, 6(7), 71. https://doi.org/10.5539/ijef.v6n7p71

Agrawal, G. (2015). Foreign direct investment and economic growth in BRICS economies: A data analysis. Journal of Economics, Business and Management, 3(4), 421-424. https://doi.org/ 10.7763/JOEBM.2015.V3.221

Agrawal, G., \& Khan, M. A. (2011). Impact of FDI on GDP: A comparative study of China and India. International Journal of Business and Management, 6(10), 71. https://doi.org/10.5539/ijbm.v6n10p71

Ali, N., \& Shaheen, R. (2019). The role of FDI in economy of Pakistan for the period of 1971-2018. European Online Journal of Natural and Social Sciences: Proceedings, 8(2s), 10 . Retrieved from http://european-science.com/eojnss_proc/article/view/5732

Ameyaw, B., Oppong, A., Abruquah, L. A., \& Ashalley, E. (2016). Causality nexus of electricity consumption and economic growth: an empirical evidence from Ghana. Open Journal of Business and Management, 5(1), 1. http://doi.org/10.4236/ojbm.2017.51001

Apergis, N., \& Danuletiu, D. C. (2014). Renewable energy and economic growth: evidence from the sign of Panel long-run causality. International Journal of Energy Economics and Policy, 4(4), 578-587. Retrieved from https://pdfs.semanticscholar.org/e70c/a9599679477aa007c8d9d85954a0f2f131ea.pdf

Aqeel, A., \& Butt, M. S. (2001). The relationship between energy consumption and economic growth in Pakistan. Asia-Pacific Development Journal, 8(2), 101-110. $\quad$ Retrieved from http://citeseerx.ist.psu.edu/viewdoc/download?doi=10.1.1.483.686\&rep=rep1\&type=pdf

Arrow, K. J. (1962). The Economic implication of learning-by-doing. Review of Economic Studies, $29(1), 155-173$. https://doi.org/10.2307/2295952

Ashraf, Z., Javid, A. Y., \& Javid, M. (2013). Electricity consumption and economic growth: evidence from Pakistan. Economics and Business Letters, 2(1), 21-32. Retrieved from https://ideas.repec.org/a/ove/journl/aid9396.html

Aslan, A. (2014). Causality between electricity consumption and economic growth in Turkey: An ARDL bounds testing approach. Energy Sources, Part B. Economics, Planning, and Policy, 9(1), $25-31$. https://doi.org/10.1080/15567241003681882

Attari, M. I. J., \& Attaria, S. N. (2011). The decomposition analysis of CO 2 emission and economic growth in Pakistan India and China. Pakistan Journal of Commerce and Social Sciences (PJCSS), 5(2), 330-343. Retrieved from http://www.jespk.net/publications/67.pdf

Bahmani-Oskooee, M., \& Brooks, T. J. (1999). Bilateral J-curve between US and her trading partners. Weltwirtschaftliches Archiv, (H. 1), 156-165. https://doi.org/10.1007/BF02708163

Bahmani-Oskooee, M., \& Harvey, H. (2006). How sensitive are Malaysia's bilateral trade flows to depreciation?. Applied Economics, 38(11), 1279-1286. https://doi.org/10.1080/00036840500405490

Balcilar, M., Bekun, F. V., \& Uzuner, G. (2019). Revisiting the economic growth and electricity consumption nexus in Pakistan. Environmental Science and Pollution Research, 26(12), 12158-12170. https://doi.org/10.1007/s11356-019-04598-0

Balcilar, M., Ozdemir, Z. A., \& Arslanturk, Y. (2010). Economic growth and energy consumption causal nexus viewed through a bootstrap rolling window. Energy Econ, 32(6), 1398-1410. https://doi.org/10.1016/j.eneco.2010.05.015

Bekhet, H. A., \& Othman, N. S. (2011). Causality analysis among electricity consumption, consumer expenditure, gross domestic product (GDP) and foreign direct investment (FDI): Case study of Malaysia. Journal of Economics and International Finance, 3(4), 228-235. Retrieved from http://www.academicjournals.org/JEIF

Bende-Nabende, A., \& Ferd, J. L. (1998). FDI, Policy Adjustments and Endogenous Growth Multiplier Effects from a Small Dynamic Model for Taiwan 1959-1995. World Development, 26(7), 115-130. https://doi.org/10.1016/S0305-750X(98)00043-6 
Chandran, V. G. R., Sharma, S., \& Madhavan, K. (2010). Electricity consumption-growth nexus: the case of Malaysia. Energy Policy, 38(1), 606-612. https://doi.org/10.1016/j.enpol.2009.10.013

CIA. (2018). Central Intelligence Agency World Fact Book (CIA-WFB) Asia Pakistan Report. Retrieved from https://www.indexmundi.com/pakistan/electricity_access.html

Cobb, C. W., \& Douglas, P. H. (1928). A theory of production. The American Economic Review, 18(1), 139-165. Retrieved from https://www.aeaweb.org/aer/top20/18.1.139-165.pdf

Cowan, W. N., Chang, T., Inglesi-Lotz, R., \& Gupta, R. (2014). The nexus of electricity consumption, economic growth and $\mathrm{CO} 2$ emissions in the BRICS countries. Energy Policy, 66, 359-368. https://doi.org/10.1016/j.enpol.2013.10.081

Dickey, D. A., \& Fuller, W. A. (1979). Distribution of the estimators for autoregressive time series with a unit root. Journal of the American statistical association, 74(366a), 427-431. https://doi.org/10.2307/2286348

Dlamini, J., Balcilar, M., Gupta, R., \& Inglesi-Lotz, R. (2015). Revisiting the causality between electricity consumption and economic growth in South Africa: a bootstrap rolling-window approach. Int J Econ Policy Emerging Economies, 8(2), 169-190. https://doi.org/10.1504/IJEPEE.2015.069595

Dunning, J. H., \& Lundan, S. M. (2008). Multinational enterprises and the global economy. Edward Elgar Publishing. Retrieved from http://www.e-elgar.com/shop/isbn/9781843765257

Engle, R. F., \& Granger, C. W. (1987). Co-integration and error correction: representation, estimation, and testing. Econometrica: Journal of the Econometric Society, 55(2), 251-276. https://doi.org/10.2307/1913236

Ford, T. C., Rork, J. C., \& Elmslie, B. T. (2008). Foreign direct investment, economic growth, and the human capital threshold: evidence from US states. Review of International Economics, 16(1), 96-113. https://doi.org/10.1111/j.1467-9396.2007.00726.x

Ghosh, S. (2002). Electricity consumption and economic growth in India. Energy Policy, 30(2), $125-129$. https://doi.org/10.1016/S0301-4215(01)00078-7

Hansen, B. E., \& Phillips, P. C. (1990). Estimation and inference in models of cointegration: A simulation study. $\begin{array}{lllll}\text { Advances in } & \text { Econometrics, } & \text { 225-248. } & \text { Retrieved }\end{array}$ http://cowles.yale.edu/sites/default/files/files/pub/d08/d0881.pdf

Hanson, G. H. (2001). Should countries promote foreign direct investment? (Vol. 9). UN. Retrieved from https://unctad.org/en/Docs/pogdsmdpbg24d9.en.pdf

Haug, A. A. (2002). Temporal aggregation and the power of cointegration tests: A Monte Carlo study. Oxford Bulletin of Economics and Statistics, 64(4), 399-412. https://doi.org/10.1111/1468-0084.00025

Jamil, F., \& Ahmad, E. (2010). The relationship between electricity consumption, electricity prices and GDP in Pakistan. Energy Policy, 38(10), 6016-6025. https://doi.org/10.1016/j.enpol.2010.05.057

Johansen, S., \& Juselius, K. (1990). Maximum likelihood estimation and inference on cointegration-with applications to the demand for money. Oxford Bulletin of Economics and Statistics, 52(2), 169-210. https://doi.org/10.1111/j.1468-0084.1990.mp52002003.x

Khan, M. A., \& Ahmad, U. (2008). Energy demand in Pakistan: a disaggregate analysis. Pakistan Development Review, 47,437-455. Retrieved from https://www.jstor.org/stable/41261233

Khawar, M. (2005). Foreign direct investment and economic growth: A cross-country analysis. Global Economy Journal, 5(1), 1850034. https://doi.org/10.2202/1524-5861.1057

Kim, S. (2019). CO2 Emissions, foreign direct investments, energy consumption, and GDP in developing countries: a more comprehensive study using panel vector error correction model. Korean Economic Review, 35, 5-24. Retrieved from http://keapaper.kea.ne.kr/RePEc/kea/keappr/KER-20190101-35-1-01.pdf

Kivyiro, P., \& Arminen, H. (2014). Carbon dioxide emissions, energy consumption, economic growth and foreign direct investment: Causality analysis for Sub-Saharan Africa. Energy, 74, 595-606. https://doi.org/10.1016/j.energy.2014.07.025

Kwiatkowski, D., Phillips, P. C., Schmidt, P., \& Shin, Y. (1992). Testing the null hypothesis of stationarity against the alternative of a unit root. Journal of Econometrics, 54(1-3), 159-178. Retrieved from http://debis.deu.edu.tr/userweb/onder.hanedar/dosyalar/kpss.pdf 
Laurenceson, J., \& Chai, J. C. (2003). Financial reform and economic development in China. Edward Elgar Publishing. Retrieved from https://ideas.repec.org/b/elg/eebook/2714.html

Lee, C. G. (2009). Foreign direct investment, pollution and economic growth: evidence from Malaysia. Applied Economics, 41(13), 1709-1716. https://doi.org/10.1080/00036840701564376

Lee, S. J. (2012). South Korea as new middle power seeking complex diplomacy. Asian Security Initiative Research Report, (25), 1-36. Retrieved from http://www.eai.or.kr/data/bbs/eng_report/2012091211454078.pdf

Linh, D. H., \& Lin, S. M. (2015). Dynamic causal relationships among CO2 emissions, energy consumption, economic growth and FDI in the most populous Asian Countries. Advances in Management and Applied Economics, 5(1), 69-88. Retrieved from http://www.scienpress.com/Upload/AMAE/Vol\%205_1_6.pdf

Long, P. D., Ngoc, B. H., \& My, D. T. H. (2018). The relationship between foreign direct investment, electricity consumption and economic growth in Vietnam. International Journal of Energy Economics and Policy, 8(3), 267-274. Retrieved from http://www.zbw.eu/econis-archiv/bitstream/handle/11159/2122/1028135211.pdf?sequence=1

Makki, S. S., \& Somwaru, A. (2004). Impact of foreign direct investment and trade on 7 economic growth: Evidence from developing countries. American Journal of Agricultural Economics, 86(3), 795-801. https://doi.org/10.1111/j.0002-9092.2004.00627.x

Mencinger, J. (2003). Does foreign direct investment always enhance economic growth?. Kyklos, 56(4), 491-508. https://doi.org/10.1046/j.0023-5962.2003.00235.x

OECD. (2007). Organization for Economic Co-Operation and Development annual report on sustainable development work. Retrieved from http://www.oecd.org/greengrowth/40015309.pdf

Ouattara, B. (2004). Modelling the long run determinants of private investment in Senegal. Credit Research Paper, (No. 04/05). Retrieved from https://www.econstor.eu/bitstream/10419/81768/1/04-05.pdf

Park, C. D., Kim, S. W., \& Park, J. G. (2019). An analysis on causalities among gdp, electricity consumption, CO2 emission and FDI inflow in Korea. Journal of Energy Engineering, 28(2), 1-17. https://doi.org/10.5855/ENERGY.2019.28.2.001

Pesaran, M. H. (1997). The role of economic theory in modelling the long run. The Economic Journal, 107(440), 178-191. Retrieved from https://www.jstor.org/stable/2235280

Pesaran, M. H., Shin, Y., \& Smith, R. J. (2000). Structural analysis of vector error correction models with exogenous I (1) variables. Journal of Econometrics, 97(2), 293-343. https://doi.org/10.1016/S0304-4076(99)00073-1

Pesaran, M. H., Shin, Y., \& Smith, R. J. (2001). Bounds testing approaches to the analysis of level relationships. Journal of Applied Econometrics, 16(3), 289-326. https://doi.org/10.1002/jae.616

Phillips, P. C., \& Perron, P. (1988). Testing for a unit root in time series regression. Biometrika, 75(2), 335-346. https://doi.org/10.1093/biomet/75.2.335

SBP. (2019). State Bank of Pakistan first quarterly report. Retrieved from http://www.sbp.org.pk/reports/quarterly/fy20/First/Complete.pdf

Sekantsi, L. P., \& Okot, N. (2016). Electricity consumption-economic growth nexus in Uganda. Energy Sources, Part B, 11(12), 1144-1149. https://doi.org/10.1080/15567249.2015.1010022

Shaari, M. S. B., Hong, T. H., \& Shukeri, S. N. (2012). Foreign direct investment and economic growth: evidence from Malaysia. International Business Research, 5(10), 100. https://doi.org/10.5539/ibr.v5n10p100

Shahbaz, M., \& Feridun, M. (2012). Electricity consumption and economic growth empirical evidence from Pakistan. Qual Quant, 46(5), 1583-1599. Retrieved from https://link.springer.com/article/10.1007/s11135-011-9468-3

Shahbaz, M., \& Feridun, M. (2012). Electricity consumption and economic growth empirical evidence from Pakistan. Quality \& Quantity, 46(5), 1583-1599. https://doi.org/10.1007/s11135-011-9468-3

Shahbaz, M., \& Lean, H. H. (2012). The dynamics of electricity consumption and economic growth: A revisit study of their causality in Pakistan. Energy, 39(1), 146-153. https://doi.org/10.1016/j.energy.2012.01.048

Shahbaz, M., Tang, C. F., \& Shabbir, M. S. (2011). Electricity consumption and economic growth nexus in Portugal using cointegration and causality approaches. Energy Policy, 39(6), 3529-3536. https://doi.org/10.1016/j.enpol.2011.03.052 
Siddiqui, F., \& Siddiqui, D. A. (2019). Causality between Tourism and Foreign Direct Investment: An Empirical Evidence from Pakistan. Asian Journal of Economic Modelling, 7(1), 27-44. Retrieved from https://papers.ssrn.com/sol3/papers.cfm?abstract_id=3397173

Tamba, J. G., Nsouandélé, J. L., Fopah Lélé, A., \& Sapnken, F. E. (2017). Electricity consumption and economic growth: evidence from Cameroon. Energy Sources, Part B, 12(11), 1007-1014. https://doi.org/10.1080/15567249.2017.1349211

Tang, C. F. (2008). A re-examination of the relationship between electricity consumption and economic growth in Malaysia. Energy Policy, 36(8), 3077-3085. https://doi.org/10.1016/j.enpol.2008.04.026

Tintin, C. (2012). Does foreign direct investment spur economic growth and development: a comparative study. Unpublished Doctoral Dissertation. Institute for European Studies, Free University of Brussels, Brussels, WP, 1-53. Retrieved from https://www.etsg.org/ETSG2012/Programme/Papers/73.pdf

Tiwari, A. K. (2011). A structural VAR analysis of renewable energy consumption, real GDP and CO2 emissions: evidence from India. Economics Bulletin, 31(2), 1793-1806. Retrieved from https://ideas.repec.org/a/ebl/ecbull/eb-10-00774.html

Toda, H. Y., \& Yamamoto, T. (1995). Statistical inference in vector auto regressions with possibly integrated processes. Journal of Econometrics, 66(1-2), 225-250. https://doi.org/10.1016/0304-4076 (94)01616-8

Umer, F., \& Alam, S. (2013). Effect of openness to trade and FDI on industrial sector growth: A case study for Pakistan. Romanian Economic Journal, 16(48), 179-198. Retrieved from https://ideas.repec.org/a/rej/journl/v16y2013i47p179-198.html

Umoh, O. J., Jacob, A. O., \& Chuku, C. A. (2012). Foreign direct investment and economic growth in Nigeria: An analysis of the endogenous effects. Current Research Journal of Economic Theory, 4(3), 53-66. Retrieved from https://www.airitilibrary.com/Publication/alDetailedMesh?docid=2042485X-201206-201507090016-20150709 0016-53-66

Wang, M. (2010). Foreign direct investment and domestic investment in the host country: Evidence from panel study. Applied Economics, 42(29), 3711-3721. https://doi.org/10.1080/00036840802314580

WDI. (2018). World development indicators (World Bank open data). Retrieved from https://data.worldbank.org/country/pakistan

Williamson, O. E. (1985). The Economic Institutions of Capitalism. The Free Press.

Zapata, H. O., \& Rambaldi, A. N. (1997). Monte Carlo evidence on cointegration and causation. Oxford Bulletin of Economics and statistics, 59(2), 285-298. https://doi.org/10.1111/1468-0084.00065

\section{Copyrights}

Copyright for this article is retained by the author(s), with first publication rights granted to the journal.

This is an open-access article distributed under the terms and conditions of the Creative Commons Attribution license (http://creativecommons.org/licenses/by/4.0/). 